\title{
Employee Job Satisfaction in Furniture Manufacturing Companies in the Slovak Republic
}

\section{Zadovoljstvo zaposlenika poslom u tvrtkama za proizvodnju namještaja u Republici Slovačkoj}

\author{
Original scientific paper • Izvorni znanstveni rad \\ Received-prispjelo: 29. 2. 2016. \\ Accepted-prihvaćeno: 6. 9. 2016. \\ UDK: $630 * 79$ \\ doi:10.5552/drind.2016.1614
}

\begin{abstract}
The research was focused on the comprehensive understanding of motivation factors that affected empoyee job satisfaction in furniture manufacturing companies in the Slovak Republic in 2015. Questionnaire analysis was selected as the key research method. Questionnaires consisted of 36 most motivating factors organized into 5 sub-cathegories, analyzed on the basis of the degree of satisfaction for respondents. Based on the collected data, top 10 motivation factors, which the employees of Slovak furniture manufacturing companies rated as the most satisfying, were identified. According to respondents, 3 most satisfying factors included physical work demands, "interestingness" of work and the ability to use the qualification. Research outcomes resulted in a series of recommendations for the furniture manufacturing companies to focus on in order to boost employee job satisfaction with regards to the fact that only well-motivated employees can increase the efficiency of the whole enterprise.
\end{abstract}

Key words: motivation factors, employee job satisfaction, furniture manufacturing companies in the Slovak Republic (FM-companies), questionnaire, statistical analysis

SAŽETAK • Istraživanje je usmjereno na cjelovito razumijevanje motivacijskih čimbenika koji utječu na zadovoljstvo zaposlenika radom u tvrtkama za proizvodnju namještaja u Republici Slovačkoj u 2015. godini. Kao glavna metoda istraživanja odabrana je analiza putem upitnika. Upitnicima je obuhvaćeno 36 motivacijskih čimbenika organiziranih u pet potkategorija, koji su analizirani na osnovi stupnja zadovoljstva ispitanika. Na temelju prikupljenih podataka, identificirano je deset motivacijskih čimbenika koje su zaposlenici ocijenili zadovoljavajućima u slovačkim tvrtkama za proizvodnju namještaja. Prema mišljenju anketiranih, tri čimbenika koja većina ispitanika smatra zadovoljavajućim jesu fizički zahtjevi posla, ,zanimljivosti“ u radu i mogućnost da se zaposlenici koriste svojim kvalifikacijama. Ishodi istraživanja rezultirali su nizom preporuka za proizvođače namještaja kako bi se usredotočili na podizanje razine zadovoljstva zaposlenika poslom jer je poznata činjenica da samo dobro motivirani zaposlenici mogu povećati učinkovitost cijelog poduzeća.

Ključne riječi: motivacijski čimbenici, zadovoljstvo zaposlenika poslom, tvrtke za proizvodnju namještaja u Slovačkoj (FM poduzeća), upitnik, statističke analize

\footnotetext{
${ }^{1}$ Author is assistant professor at Faculty of Wood Science and Technology, Technical University in Zvolen, Zvolen, Slovakia. ${ }^{2}$ Author is assistant professor at Faculty of Wood Science and Technology, Technical University in Zvolen, Zvolen, Slovakia. ${ }^{3}$ Author is associate professor at Faculty of Arts, Matej Bel University, Banská Bystrica, Slovakia.

Autorica je docentica Tehničkog sveučilišta u Zvolenu, Fakultet znanosti o drvu i tehnologiju, Zvolen, Slovačka. ${ }^{2}$ Autorica je docentica Tehničkog sveučilišta u Zvolenu, Fakultet znanosti o drvu i tehnologiju, Zvolen, Slovačka. ${ }^{3}$ Autor je izvanredna profesorica na Filozofskom fakultetu Sveučilišta Matej Bel, Banská Bystrica, Slovačka.
} 


\section{INTRODUCTION}

\section{UVOD}

Business cannot be regarded as a closed and isolated system as the world financial crisis has influenced the whole entrepreneur society (Marková and Lesníková, 2015; Vetráková et al., 2013). Turbulent changes influenced by the world business depression have created an absolutely new set of conditions for the operation of various entrepreneurs. To be able to react to the said changes and to ensure their continuous sustainable development, it is necessary to optimize their performance (Čambál and Cagáňová, 2010). Against the background of increasing local and global competitiveness, it is crucial for any organization to ensure that it consistently develops and retains a loyal, committed and able workforce. This presupposes employees who are satisfied with the work that they do and with the culture of the organization that they are employed by and who are consequently motivated to continue their relationship with that organization (Roos et al., 2008). Hitka and Štípalová (2011) take a similar view according to which the existence of the enterprise, its prosperity and dynamic progress are primarily affected by the quality of human resources. Kucharčíková (2014) also considers human resources as significant production input for economies and companies. As performance of employees is significant for organizations, the management should consider improving the performance of workers in their companies by encouraging them to do their tasks and duties as efficiently and effectively as possible. Therefore, motivation in firms is absolutely important and necessary because it could change the behaviour of employees in positive ways. That is why many managers believe that when they establish motivated employees in the workplace, they can observe significant achievements in their organizations (Aarabi et al., 2013).

Human resources management is one of the most important parts of the business. Success of the whole enterprise depends on human resources management (Vaníčková, 2015). One of the most important and at the same time the most difficult task of human resources management is motivation of employees (Hitka et al., 2011). For better understanding the role of motivation, the meaning of motivation should be made clear. Motivation is a Latin word and it means "to move" (Wade \& Tavris, 2008). Motivation can be defined in a number of ways. At a fairly straightforward level, it could be described as: "What makes us do what we do" (Bagshawe, 2011). Psychologists believe that motivation is the process that drives an individual towards achieving a goal. Moreover, motivation gives a person a purpose and the drive that he needs to achieve it. It helps people to push or pull from a bad situation, which are negative features in their lives (Aarabi et al., 2013). Halepota (2005) defines motivation as “a person's active participation and commitment to achieve the prescribed results". Without motivation, employees cannot offer their best, meaning that they are less efficient in the company's performance. According to Antomio- ni (1999), the amount of effort people are willing to put in their work depends on the degree to which they feel their motivational needs will be satisfied. Greenberg and Baron (2003) define motivation as: "The set of processes that arouse, direct, and maintain human behavior towards attaining some goal". Motivation, in general, is more or less basically concerned with factors or events that move, lead, and drive certain human action or inaction over a given period of time under the prevailing conditions (Kachalla, 2014).

Thanks to globalization, the requirements on the quality of human resources are increasing (Kampf et al., 2015). Nowadays, nobody doubts that success of every company on the global market depends, in a great extent, on how fast it can adjust to quick changes of the business environment. This is also one of the reasons why human capital is becoming a crucial and more valuable factor as technology, processes and organizational structure can be copied but the value that competent and dedicated employees can bring to companies cannot be easily taken away (Antošová, 2010; Ahmad et al., 2012). Times, when the main role of a manager or supervisor in the workplace was to assign tasks to employees, are over. Employees want to be familiar with the business process and not only to be paid. To provide higher productivity, they are expected to work with responsibility and to contribute to successful achievement of the company goals (Hitka et al., 2015). For traditional approaches of business performance measurement, the most important objective is the maximization of profit but prosperous enterprises realize that the most profitable capital of the enterprise is its employees and their motivation, through which an enterprise can successfully meet its objectives (Potkány et al., 2014). Moynihan and Pandey (2007) have pointed out that the organizational effectiveness depends on how organizations manage their employees. Motivated employees are needed to ensure the operational health of each organization. This is because motivated employees help businesses to succeed, as they are more productive (Alnıçık et al., 2012). Hence, motivated employees can contribute to making an organization more valuable and profitable (McKenzie-Mohr \& Schultz, 2014). To be effective, managers need to understand what motivates employees within the context of the roles they perform (Noor et al., 2016). Of all the functions a manager performs, motivating employees is arguably the most complex. This is partly due to the fact that what motivates employees changes constantly (Bowen \& Radhakrishna, 1991). For example, when an employee's income increases, money becomes less of a motivator (Kovach, 1987). Therefore, it is crucial to understand the factors that may cause the changes in employee motivation. Anitha (2014) identified six factors increasing employee's motivation such as working environment, management, training and professional development, wages, working place, team work and relationship to co-workers. Imhof, however, as early as in 2003, suggested and analyzed a wider spectrum of motivation factors than Anitha (2014). Imhof's factors included: healthy working conditions, career opportunity, supportive boss, unambiguous and definite goals, 
competitive compensation, stable place of work, interesting job, high prestige, good performance evaluation, pleasant working atmosphere, peaceful private life, competent leadership, appreciation, participation in decision-making and fringe benefits. Nevertheless, there are many more factors that influece employee motivation. Therefore, we have extended the overall scope of motivation factors to 36 (Table 1) and these were further divided into five sub-cathegories related to the nature of work, physical conditions of work, economic conditions of work, technical and logistic conditions of work, interpersonal relationships at workplace. The aim of the research was focused on the comprehensive understanding of motivation factors that affected empoyee job satisfaction in furniture manufacturing companies in the Slovak Republic in 2015.

All organizations aim to have workers who will become key employees that the organization will retain over the long term. Therefore, the motivation factors and values that affect the quality of a worker's performance must be systematically explored because if a manager does not find the right way to motivate staff, workplace absenteeism and fluctuation will rise and taking breaks in an inappropriate way (surfing the Internet, private phone calls), interruption, intrigues, conflicts, dissatisfaction with management will be more obvious (Urbancová et al., 2015). At the same time interest in work, quality and productivity at work, willingness to become responsible, level of submitting proposals, concentration at work, personal participation of an employee and punctuality are declining (For- syth, 2003). Early research has reported that unsatisfied employees show lower job performance and leave their jobs more often than satisfied employees (Judge et al., 2001; Hellman, 1997).

\section{MATERIAL AND METHODS \\ 2. MATERIJAL I METODE}

In order to acquire empirical data, a questionnaire method, with regards to multiple benefits, has been selected as the key research method. Among other positives, questionnaires enable collecting of respondents opinions and attitudes in a short period of time and the follow-up bulk data processing. Additonal relevant information about the respondents (such as age, education and other identification data) can also be collected. Anonymous questionnaires further enhance opennes and sincerity of respondents. Finally, in comparison with a personal debate, questionnaires are less stressful and responses are less affected by the atmosphere and the place. The main part of the questionnaires included closed type questions focused on the level of motivation analyzed through motivation factors in the particular company measured by the level of satisfaction for respondents. Motivation factors were further cathegorized into 5 sub-cathegories according to Table 1.

The total number of 36 motivation factors has been analyzed by the extrapolation method. Respondents were asked to match each motivation factor with 5-point rating scale of satisfaction indexes, $1=$ minimum and $5=$ maximum $($ Table 2$)$.

Table 1 Analyzed motivation factors

Tablica 1. Analizirani čimbenici motivacije

\begin{tabular}{|l|l|}
\hline The nature of work & Technical and logistic conditions of work \\
1. "Interestingness" of work & 21. Technical equipment of the workplace \\
2. Variability of work & 22. Working hours \\
3. Independence at work & 23. Flow of work \\
4. Usefulness of one's qualification & 24. Organization of work \\
5. Physical work demands & 25. Work distribution \\
6. Education and personal growth & \\
7. Work content & Interpersonal relationships at workplace \\
\hline Physical conditions of work & 26. Working team \\
8. Overall workplace equipment & 27. Workplace atmosphere \\
9. Space & 28. The manner of decision-making \\
$\begin{array}{l}\text { 10. Work environment } \\
\text { 11. Work safety }\end{array}$ & 29. Employer-employee relationship \\
12. Anti-dust precautions & 30. Criticisism by superiors \\
\hline Economic conditions of work & 31. Recognition of one's performance by superiors \\
13. Job security & 32. The manner of work distribution \\
14. Salary & 33. Information about current affairs in the company \\
15. Financial benefits and rewards & 34. Information about work distribution \\
16. Social services & 35. Just system of rewarding \\
17. Company reputation & 36. Opportunity to express one's opinion \\
18. Promotion potential & \\
19. Company's ecological policy & \\
20. Extra-work activities & \\
\hline
\end{tabular}

Table 2 5-point rating scale: the degree of satisfaction

Tablica 2. Rangiranje motivacijskih čimbenika u pet razina: stupnjevi važnosti i zadovoljstva

\begin{tabular}{|l|c|c|c|c|c|}
\hline & $\mathbf{1}$ & $\mathbf{2}$ & $\mathbf{3}$ & $\mathbf{4}$ & $\mathbf{5}$ \\
\hline $\begin{array}{l}\text { The degree of satisfaction } \\
\text { Stupanj zadovoljstva }\end{array}$ & Very dissatisfied & Dissatisfied & Quite satisfied & Satisfied & Very satisfied \\
Vrlo nezadovoljan & Nezadovoljan & Relativno zadovoljan & Zadovoljan & Vrlo zadovoljan \\
\hline
\end{tabular}


Pre-research and questionnaire pilot-testing to minimize inadequacities was conducted in 3 companies. After innitial error elimination, questionnaires were distributed in FM-companies, specifically, in companies focused on complex furniture manufacturing and shipping and on custom-based interiors. However, according to the Slovak Bureau of Statistics, there were as many as 76 furniture companies registered in Slovakia in 2013 with 9,594 average numbers of registered employees and, therefore, the whole sampling unit could not be analyzed. Generally, the larger the sampling unit is, the more accurate and confident results will be acquired; proportionally, however, expenses and efforts rise. Therefore, it was essential to strike balance between the sampling unit size and desired accuracy, confidence and effectiveness of survey. In order to calculate the minimum sampling unit size $(n)$ the mathematical relation has been used, where $n$ is the function of desired confidence and accuracy at certain estimated variability of analyzed phenomena in the sampling unit. Given the 95 $\%$ confidence secured by the tabular value $z_{0.025}=1.96$, desired accuracy $\Delta x=0.05$ and average variability of responses according to the satisfacion scale of various motivation factors, given by variance of $\sigma_{x}^{2}=0.3$, a minimum number of respondents has been set as follows:

$$
n=\frac{1.96^{2} \cdot 0.3}{0.05^{2}}=461 \text { respondents }
$$

The minimum sampling unit size has been set at pre-defined 0.05 accuracy and $95 \%$ confidence criteria. 461 returned questionnaires were thus the necessary minimum to meet the pre-defined accuracy and confidence requirements. In order to collect the necessary set of questionnaries and well aware of the low turnover of e-questionnaires, three times more questionnaires $(1,500)$ were distributed between June 2015 and October 2015. In October 2015, 522 valid questionnaires (sampling unit size of this research) were correctly completed and returned. The overall questionnaire response rate was thus $34.80 \%$, which meets the minimum sampling unit size criterion.

Structure of sampling unit: $20.69 \%$ women and $79.31 \%$ men participated in the research; a majority of them were manual workers $(75.86 \%)$, only $24.14 \%$ were managers. A majority of respondents were $31-40$ years old $(48.28 \%)$. The same percentage, $48.28 \%$ of

Table 3 Variance - decomposition into individual items Tablica 3. Raspadanje komponenata disperzije

\begin{tabular}{|c|c|c|c|}
\hline $\begin{array}{c}\text { Variance } \\
\text { Varijan- } \\
c a\end{array}$ & $\begin{array}{c}\text { Sum of square } \\
\text { deviations } \\
\text { Zbroj kvadrata } \\
\text { odstupanja }\end{array}$ & $\begin{array}{c}\text { Degree of } \\
\text { freeom } \\
\text { Stupanj } \\
\text { slobode }\end{array}$ & Variance \\
\hline $\begin{array}{c}\text { Inter- } \\
\text { group }\end{array}$ & $s_{M}=n \sum_{j=1}^{k}\left(\bar{x}_{j}-\bar{x}\right)^{2}$ & $v_{M}=k-1$ & $s_{M}^{2}=\frac{s_{M}}{v_{M}}$ \\
\hline $\begin{array}{c}\text { Residual } \\
\text { (intra- } \\
\text { group) }\end{array}$ & $s_{R}=\sum_{j=1}^{k} \sum_{i=1}^{n}\left(x_{j i}-\bar{x}_{j}\right)^{2}$ & $v_{R}=k(n-1)$ & $s_{R}^{2}=\frac{s_{R}}{v_{R}}$ \\
\hline Total & $s_{C}=\sum_{j=1}^{k} \sum_{i=1}^{n}\left(x_{j i}-\bar{x}\right)^{2}$ & $v=k \cdot n-1$ & $s_{C}^{2}=\frac{s_{C}}{v}$ \\
\hline
\end{tabular}

respondents, had lower secondary education (without a school leaving exam/certificate). $58.62 \%$ respondents have been working in the company for $6-8$ years. No respondents younger than 20 years and older than 50 years, and no respondents with only primary education or those who have been working for the company for more than 10 years participated in the research.

Survey results were processed by mathematical-statistical methods, using the statistical software program STATISTICA 12. Except for the descriptive statistics, inductive statistics method such as specific interval estimates and one-way analysis of variance which, based on testing of hypotheses, enabled generalizing of results, were used to process the data. (Note: in spite of the term "variance analysis", what we really mean is the test of equality of $k$ averages). The null hypothesis $\mathrm{H}_{0}: \mu_{1}=\mu_{2}=\ldots=\mu_{\mathrm{k}}$ was tested and compared with an alternative hypothesis $\mathrm{H}_{1}$. In the context of the overall research, $\mathrm{H}_{0}$ was tested: average results of satisfaction in 10 observed motivation factors are the same when compared with $\mathrm{H}_{1}$ : at least two motivation factors differ in average satisfaction values. By this, the fact can be confirmed that FM-employees view these factors differently in terms of their job satisfaction. The key of research thus lies in the analysis of variance into its individual items.

$$
\text { Testing criterium } F_{0}=\frac{s_{M}^{2}}{s_{R}^{2}} \text { is } F \text {-devided with } v_{\mathrm{M}} \text {, }
$$

$v_{\mathrm{R}}$ degrees of freedom. If $F_{0}>F_{\alpha}\left(v_{\mathrm{M}}, v_{\mathrm{R}}\right)$, then $\mathrm{H}_{0}: \mu_{1}=$ $\mu_{2}=\ldots=\mu_{\mathrm{k}}$ is rejected in favor of $\mathrm{H}_{1}$, which means that there are statistically significant differences between $k$ averages. "Post hoc" tests (Duncan test) were used to provide a more detailed evaluation and to identify the groups with significantly different averages. The aim of this testing was to prove which pairs of motivation factors differ in average satisfaction values and which are similar or the same. Duncan's multiple-range test is based on the comparison of the range of a subset of the sample means with a calculated least significant range. If the range of the subset exceeds the least significant range, then the population means can be considered significantly different. It is a sequential test and so the subset with the largest range is compared first, followed by smaller subsets. Once a range is found not to be significant, no further subsets of this group are tested. The least significant range, $R p$, for subsets of $p$ sample means is given by:

$$
R_{p}=r_{p} \sqrt{\frac{s^{2}}{n}}
$$

where $r_{p}$ is called the least significant studentized range and depends upon the error degrees of freedom and the numbers of means in the subset, $n$ is the sample size, and $s^{2}$ is the error mean square from the analysis of variance table (Bewick et al., 2004).

\section{RESULTS AND DISCUSSION 3. REZULTATI I RASPRAVA}

The first part of the questionnaire gathered data on the degree of motivation according to employee job 


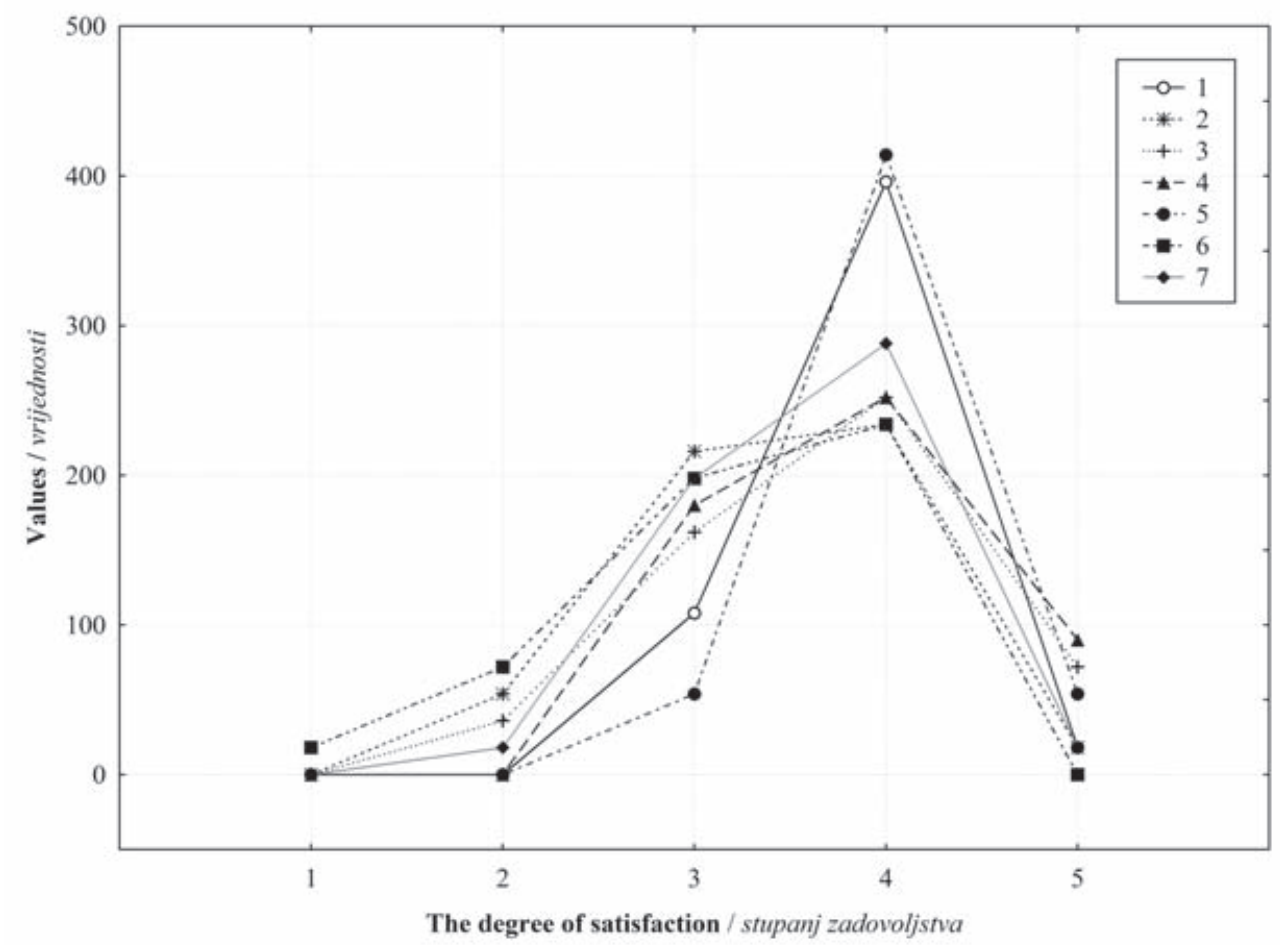

Figure 1 Absolute multiplicity of respondents evaluating motivation factors related to the criteria of nature of work Slika 1. Apsolutna raznovrsnost ispitanika pri vrednovanju motivacijskih čimbenika koji se odnose na kriterije prirode posla

satisfaction. Respondents responded to the spectrum of motivation factors, ordered according to the degree of their satisfaction. Following figures represent absolute multiplicity of respondents evaluating motivation factors organized into 5 sub-cathegories based on Table 1 . Figures match 5-point rating scale where satisfaction indexes represent 1 = very dissatisfied, 2 = dissatisfied,
$3=$ quite satisfied, $4=$ satisfied and $5=$ very satisfied (Table 2).

Based on the gathered data, in the area of nature of work, the following conclusion can be drawn: 79.31 $\%$ of respondents were "satisfied" with their physical work demands and $75.86 \%$ were "satisfied" with the "interestingness" of work. As many as $41.38 \%$ of em-

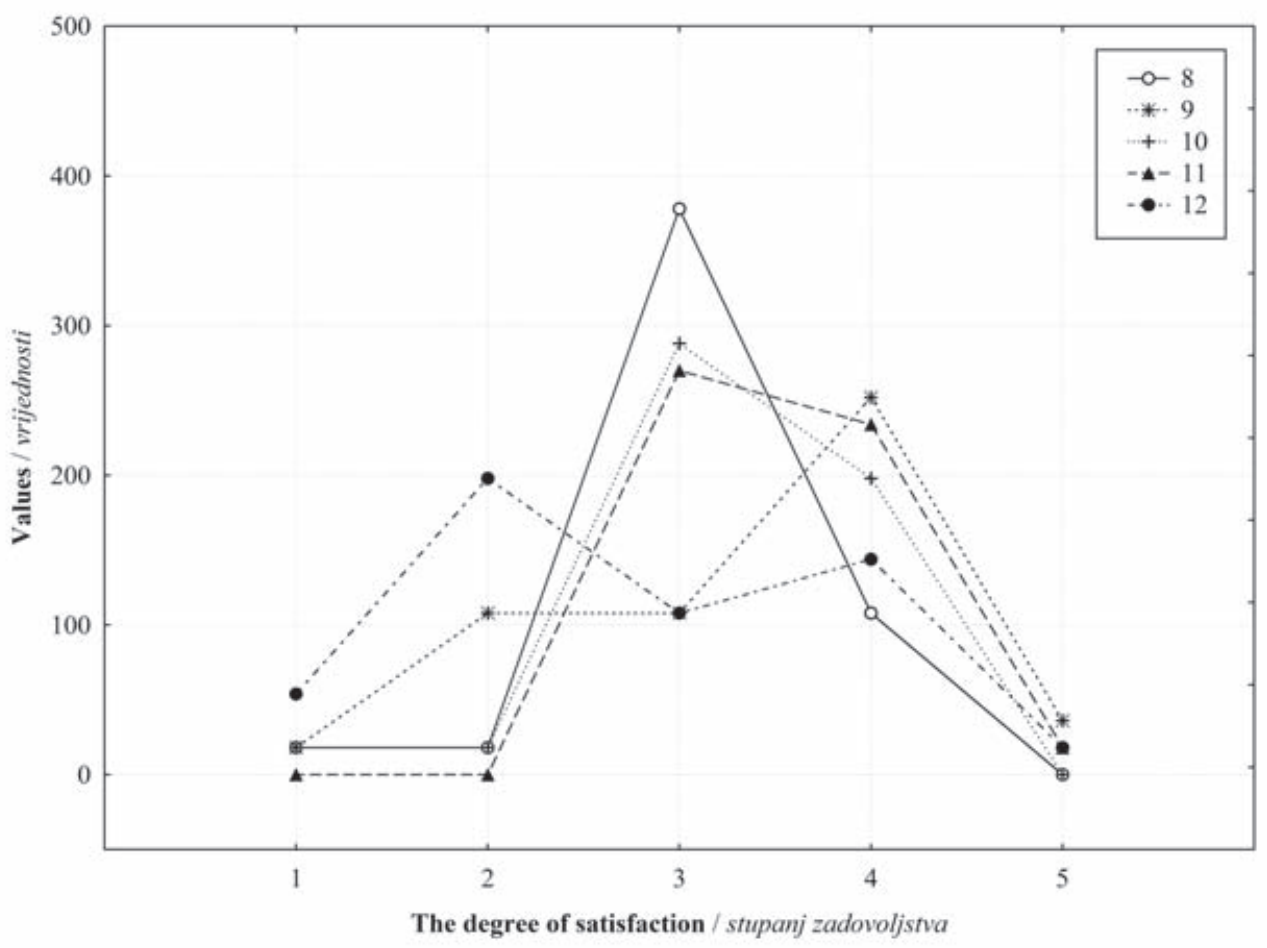

Figure 2 Absolute multiplicity of respondents evaluating motivation factors related to the criteria of physical conditions of work Slika 2. Apsolutna raznovrsnost ispitanika pri vrednovanju motivacijskih čimbenika koji se odnose na kriterije fizičkih uvjeta rada 


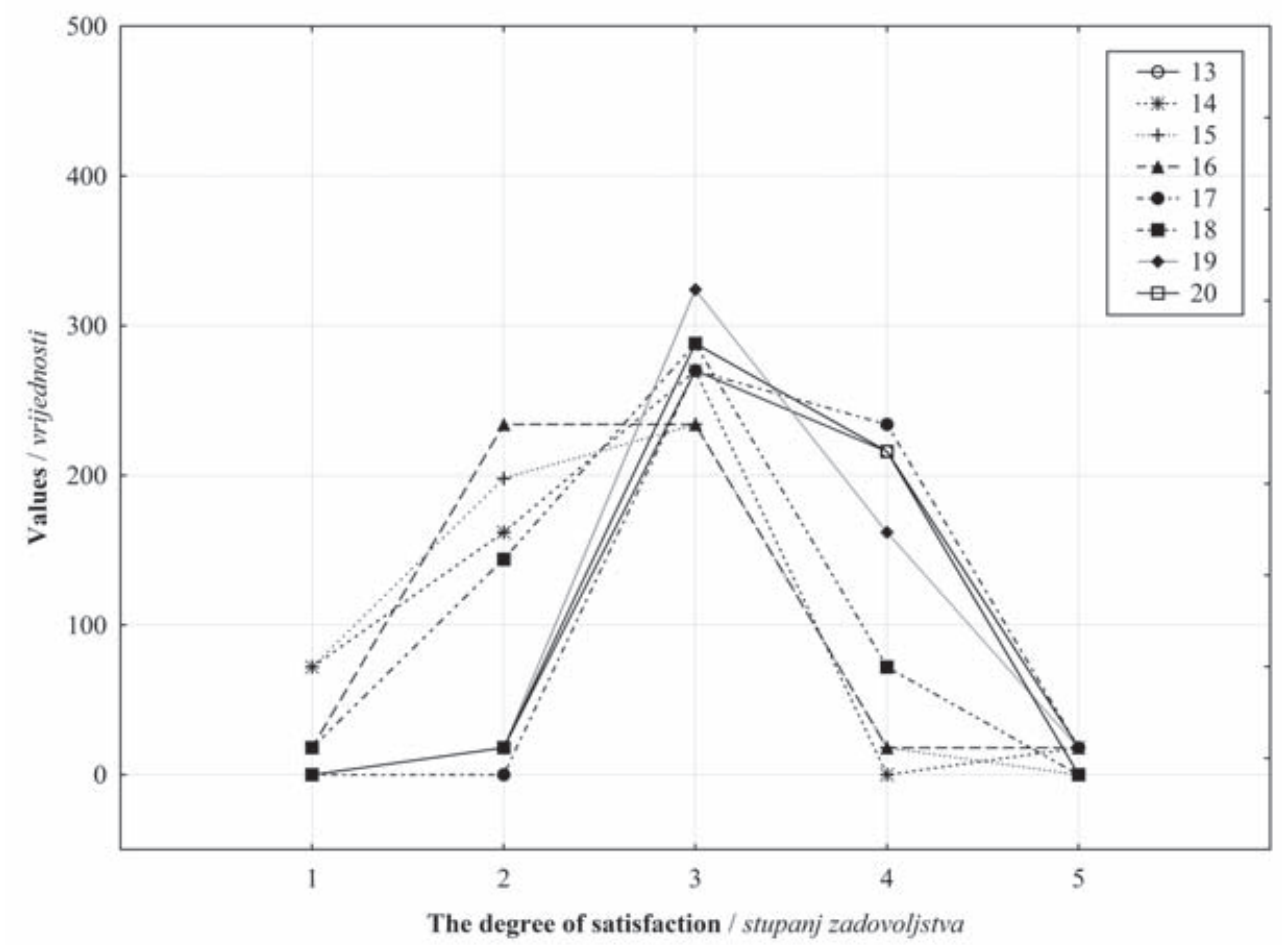

Figure 3 Absolute multiplicity of respondents evaluating motivation factors related to the criteria of economic conditions of work

Slika 3. Apsolutna raznovrsnost ispitanika pri vrednovanju motivacijskih čimbenika koji se odnose na kriterije ekonomskih uvjeta rada

Source: autors

ployees were "quite satisfied" with the varibility of work. In the field of education and personal growth, $13.79 \%$ of respondents were "dissatisfied" and $3.35 \%$ were "very dissatisfied" with the educational and personal growth potential in their company.

In the field of physical conditions of work, very low number of repondents rated the analyzed factors as "very satisfactory". Only $6.90 \%$ of respondents were "very satisfied" with work safety and only $3.45 \%$ with anti-dust precutions. Many respondents rated most criteria with lower ratings, mostly as "quite satisfying". For example, as many as $72.41 \%$ were "quite satisfied" with the workplace equipment, $55.17 \%$ with their workplace equipment and $51.72 \%$ with work safety. Respondents were seriously dissatisfied with anti-dust precautions $-37.93 \%$ of respondents were "dissatisfied" and $10.34 \%$ were "very dissatisfied".

$3.35 \%$ of employees expressed their maximum satisfaction with job security, salary, company's reputation and their company's ecological policy. Salary proved to be one of the most crucial motivation factors. Ony $3.35 \%$ of respondents were "very satisfied", $31.03 \%$ were "dissatisfied" and $13.79 \%$ were "very dissatisfied". What needs to be taken into consideration is the fact that as many as $62.07 \%$ of respondents considered salaries to be "the most important factor".

As long as the organization of work is concerned, respondents rated work organization $(10.34 \%)$ and the flow of work $(6.90 \%)$ as "very satisfactory". $62.07 \%$ of respondents were "quite satisfied" with the technical equipment of their workplace and $55.17 \%$ with work distribution.
Only $3.45 \%$ of respondents were "very satisfied" with interpersonal relationships at their workplaces, including their working team, workplace atmosphere, employer-employee relationships, superior's recognition and with the opportunity to express one's opinion. Interpersonal relationships and related factors were generally rated very low, especially those considering superior's recognition $(24.14 \%)$, criticizing by superior and just rewarding system (both factors acquired $20.69 \%$ ). These factors proved to be most sensitively perceived by the employees.

Table 4 presents motivation factors, ordered by satisfaction, as rated by respondents. 10 bold-marked motivation factors acquired the highest values of selected averages. Except for selected averages and standard deviations, Table 4 presents $95 \%$ confidence intervals for sampling unit averages. Based on the results, generalizations can be made. For example, when considering the motivation factor "salary", the respondents will evaluate this motivation factor by average value of $2.41-2.56$ with $95 \%$ confindence.

Based on collected data, the research outcomes can now be generalized and further assumptions made. The research has proved that employees were generally satisfied with physical work demands. Based on the statistical data analysis, it can be assumed, with a 95\% confidence, when FM-company employees would rate the factor "physical work demands" by an interval rating from 3.96 to 4.04 in a similar survey. The second and third place among most satisfying motivation factors are "interestedness" of work and usefulness of 


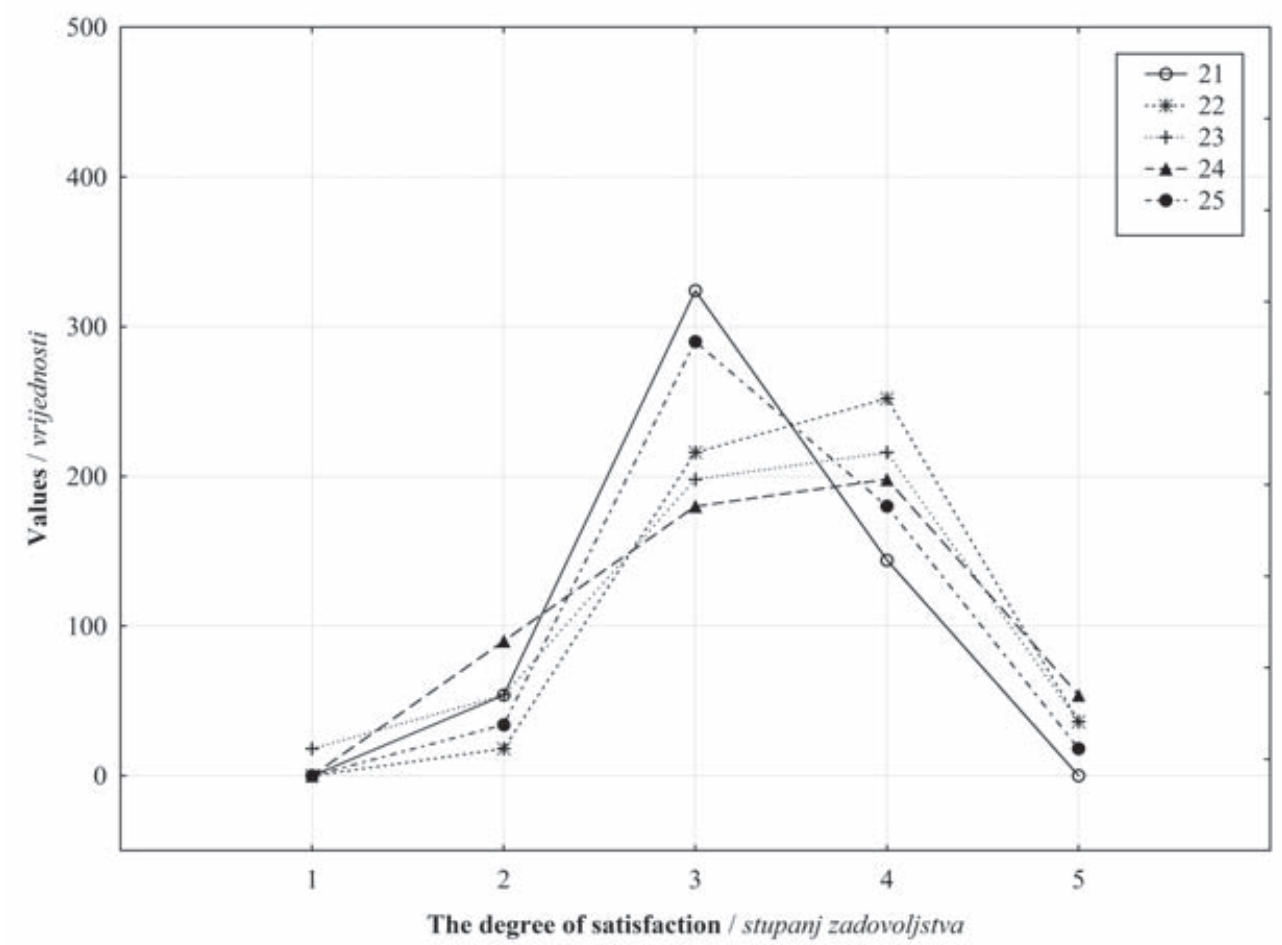

Figure 4 Absolute multiplicity of respondents evaluating motivation factors related to the criteria of technical and logistics conditions of work

Slika 4. Apsolutna raznovrsnost ispitanika pri vrednovanju motivacijskih čimbenika koji se odnose na kriterije tehničkih i logističkih uvjeta rada

one's qualification. Independence and the content of work were also among top 5 most satisfying factors.

Top 10 motivation factors that proved to be most satisfying were subject to a more detailed analysis based on Table 5 .
By one-way analysis of variance with $\mathrm{a}=5 \%$, it has been verified that average values of importace of 10 motivation factors are statistically significantly different $(p=0.000)$. Based on the follow-up post-hoc tests (Duncan test $\mathrm{a}=5 \%$ ), signifiant differences have



Figure 5 Absolute multiplicity of respondents evaluating motivation factors related to the criteria of interpersonal relationships at workplace

Slika 5. Apsolutna raznovrsnost ispitanika pri vrednovanju motivacijskih čimbenika koji se odnose na kriterije međuljudskih odnosa na radnome mjestu 
Table 4 Motivation factors, ordered according to the criterion: the degree of satisfaction

Tablica 4. Motivacijski čimbenici, redoslijed prema kriteriju stupanj zadovoljstva

\begin{tabular}{|c|c|c|c|c|}
\hline \multirow{2}{*}{$\begin{array}{l}\text { Motivation factor } \\
\text { Motivacijski čimbenik }\end{array}$} & \multirow{2}{*}{$\begin{array}{l}\text { Average } \\
\text { Prosječno }\end{array}$} & \multirow{2}{*}{$\begin{array}{c}\text { Standard } \\
\text { deviation } \\
\text { Standardno } \\
\text { odstupanje }\end{array}$} & \multicolumn{2}{|c|}{$\begin{array}{l}\text { Confidence interval } 95 \% \\
\text { Interval pouzdanosti } 95 \%\end{array}$} \\
\hline & & & $\begin{array}{c}\text { Low limit } \\
\text { Donja } \\
\text { granica }\end{array}$ & $\begin{array}{c}\text { Top limit } \\
\text { Gornja } \\
\text { granica }\end{array}$ \\
\hline Physical work demands / zahtjevi za fizičkim radom & 4.00 & 0.45 & 3.96 & 4.04 \\
\hline "Interestingness” of work ,zanimljivosti“ posla & 3.83 & 0.46 & 3.79 & 3.87 \\
\hline Usefulness of one's qualification / korisnost nečije kvalifikacije & 3.82 & 0.70 & 3.77 & 3.89 \\
\hline Work independence / neovisnost u poslu & 3.69 & 0.79 & 3.62 & 3.76 \\
\hline Content of work / sadržaj rada & 3.59 & 0.62 & 3.53 & 3.64 \\
\hline Working hours / radni sati & 3.58 & 0.67 & 3.53 & 3.64 \\
\hline Work safety / zaštita na radu & 3.52 & 0.57 & 3.47 & 3.57 \\
\hline Company's reputation / ugled tvrtke & 3.51 & 0.56 & 3.46 & 3.56 \\
\hline Job security / sigurnost radnog mjesta & 3.45 & 0.62 & 3.40 & 3.50 \\
\hline Variability of work / varijabilnost rada & 3.41 & 0.72 & 3.35 & 3.48 \\
\hline Work organization / organizacija rada & 3.41 & 0.89 & 3.34 & 3.49 \\
\hline Extra-work activities / ekstra radne aktivnosti & 3.38 & 0.55 & 3.33 & 3.43 \\
\hline Flow of work / protok posla & 3.37 & 0.89 & 3.30 & 3.46 \\
\hline Work distribution / raspodjela posla & 3.36 & 0.65 & 3.29 & 3.41 \\
\hline Company's ecological policy / ekološka politika tvrtke & 3.35 & 0.60 & 3.29 & 3.40 \\
\hline Space / prostor & 3.34 & 0.99 & 3.26 & 3.43 \\
\hline Work environment / radno okružje & 3.28 & 0.69 & 3.22 & 3.34 \\
\hline Working team / radni tim & 3.25 & 0.77 & 3.18 & 3.31 \\
\hline Education and personal growth / obrazovanje i osobni razvoj & 3.24 & 0.82 & 3.17 & 3.31 \\
\hline $\begin{array}{l}\text { Workplace technical equipment / tehnička oprema na radnome } \\
\text { mjestu }\end{array}$ & 3.17 & 0.59 & 3.12 & 3.22 \\
\hline Workplace equipment / radna oprema & 3.10 & 0.61 & 3.05 & 3.16 \\
\hline The manner of decision-making / način odlučivanja & 3.03 & 0.41 & 3.00 & 3.07 \\
\hline Workplace atmosphere / atmosfera na radnome mjestu & 3.00 & 0.79 & 2.93 & 3.07 \\
\hline $\begin{array}{l}\text { Information about work distribution / informacije o raspodjeli } \\
\text { posla }\end{array}$ & 2.99 & 0.70 & 2.94 & 3.06 \\
\hline $\begin{array}{l}\text { The manner of work assignaments / način dodjele radnih } \\
\text { zadataka }\end{array}$ & 2.90 & 0.61 & 2.84 & 2.95 \\
\hline Promotion potential / promotivni potencijal & 2.79 & 0.71 & 2.73 & 2.86 \\
\hline Anti-dust precautions / mjere zaštite od prašine & 2.77 & 1.07 & 2.67 & 2.85 \\
\hline $\begin{array}{l}\text { Employer-employee relationship / odnos poslodavca i zapos- } \\
\text { lenika }\end{array}$ & 2.76 & 0.97 & 2.68 & 2.84 \\
\hline $\begin{array}{l}\text { Opportunity to express one's opinion / mogućnosti izražavanja } \\
\text { osobnog mišljenja }\end{array}$ & 2.75 & 0.90 & 2.67 & 2.83 \\
\hline Criticism of superiors / kritičnost nadređenih & 2.69 & 1.12 & 2.59 & 2.79 \\
\hline $\begin{array}{l}\text { Information about company current affairs / informacije o } \\
\text { trenutačnim aktivnostima tvrtke }\end{array}$ & 2.62 & 0.72 & 2.56 & 2.68 \\
\hline Social services / socijalne usluge & 2.59 & 0.77 & 2.52 & 2.65 \\
\hline Salary / plaća & 2.48 & 0.86 & 2.41 & 2.56 \\
\hline Financial benefits and rewards / financijske prednosti i nagrade & 2.38 & 0.76 & 2.31 & 2.45 \\
\hline Just rewarding system / pravedan sustav nagrađivanja & 2.37 & 0.85 & 2.31 & 2.44 \\
\hline Superior's recognition / priznanje nadređenih & 2.35 & 1.03 & 2.26 & 2.43 \\
\hline
\end{tabular}

also been identified in the rating of importance among motivation factors in individual pairs. In Table 5, under the diagonal line, $p$-level pairs of motivation factors with statistically significant differences in the degree of satisfaction are highlighted. It has been observed that pairs of motivation factors with $p<0.05$ significantly differ in average satisfaction results, which means that Slovak employees working in furniture company rate these factors differently in terms of their satisfaction.

Top 10 motivation factors that proved to be the most satisfying for FM-company employees can be furhter devided into $5 \mathrm{sub}$-cathegories according to the degree of satisfaction, which, however, significantly differ. Intra-group motivation factors were, according to the employee satisfaction criterion, rated as equally satisfying.

The first group with the highest degree of satisfaction is represented by the physical work demands factor. "Interestingness" of work and usefulness of one's qualification represent the second group of motivation factors. The third group is only represented by a single factor, work independence. The fourth group includes 4 factors: the content of work, working hours, work safety and company's reputation. The last, fifth 
Table 5 Results of tested pairs of motivating factors, ordered according to the criterion: the degree of satisfaction

Tablica 5. Rezultati ispitivanih parova motivirajućih čimbenika: redoslijed prema kriteriju stupanj zadovoljstva

\begin{tabular}{|c|c|c|c|c|c|c|c|c|c|c|c|}
\hline \multicolumn{12}{|c|}{$\begin{array}{c}\text { Duncan's test, Marked differences are statistically significant at } \mathbf{p}<.05000 \text { level } \\
\text { Duncanov tes, označene su razlike statistički značajne uz } p<.05000\end{array}$} \\
\hline & & $\{1\}$ & $\{2\}$ & $\{3\}$ & $\{4\}$ & $\{5\}$ & $\{6\}$ & $\{7\}$ & $\{8\}$ & $\{9\}$ & $\{10\}$ \\
\hline & & $\mathrm{M}=4.000$ & $\mathrm{M}=3.828$ & $\mathrm{M}=3.828$ & $\mathrm{M}=3.690$ & $\mathrm{M}=3.586$ & $\mathrm{M}=3.586$ & $\mathrm{M}=3.517$ & $\mathrm{M}=3.517$ & $\mathrm{M}=3.448$ & $\mathrm{M}=3.414$ \\
\hline $\begin{array}{l}\text { Physical work } \\
\text { demands } \\
\text { zahtjevi za } \\
\text { fizičkim radom }\end{array}$ & $\{1\}$ & & 0.000 & 0.000 & 0.000 & 0.000 & 0.000 & 0.000 & 0.000 & 0.000 & 0.000 \\
\hline $\begin{array}{l}\text { "Interesting- } \\
\text { ness” of work } \\
\text { „zanimljivosti“" } \\
\text { posla }\end{array}$ & $\{2\}$ & 0.000 & & 1.000 & 0.000 & 0.000 & 0.000 & 0.000 & 0.000 & 0.000 & 0.000 \\
\hline $\begin{array}{l}\text { Usefulness of } \\
\text { one's qualifica- } \\
\text { tion / korisnost } \\
\text { zaposlenikove } \\
\text { kvalifikacije }\end{array}$ & $\{3\}$ & 0.000 & 1.000 & & 0.001 & 0.000 & 0.000 & 0.000 & 0.000 & 0.000 & 0.000 \\
\hline $\begin{array}{l}\text { Work indepen- } \\
\text { dence } \\
\text { neovisnost } u \\
\text { poslu }\end{array}$ & $\{4\}$ & 0.000 & 0.000 & 0.001 & & 0.008 & 0.010 & 0.000 & 0.000 & 0.000 & 0.000 \\
\hline $\begin{array}{l}\text { Content of } \\
\text { work } \\
\text { sadržaj rada }\end{array}$ & $\{5\}$ & 0.000 & 0.000 & 0.000 & 0.008 & & 1.000 & 0.092 & 0.105 & 0.001 & 0.000 \\
\hline $\begin{array}{l}\text { Working hours } \\
\text { radni sati }\end{array}$ & $\{6\}$ & 0.000 & 0.000 & 0.000 & 0.010 & 1.000 & & 0.075 & 0.092 & 0.001 & 0.000 \\
\hline $\begin{array}{l}\text { Work safety } \\
\text { zaštita na radu }\end{array}$ & $\{7\}$ & 0.000 & 0.000 & 0.000 & 0.000 & 0.092 & 0.075 & & 1.000 & 0.092 & 0.013 \\
\hline $\begin{array}{l}\text { Company's } \\
\text { reputation } \\
\text { ugled tvrtke }\end{array}$ & $\{8\}$ & 0.000 & 0.000 & 0.000 & 0.000 & 0.105 & 0.092 & 1.000 & & 0.075 & 0.010 \\
\hline $\begin{array}{l}\text { Job security } \\
\text { sigurnost } \\
\text { radnog mjesta }\end{array}$ & $\{9\}$ & 0.000 & 0.000 & 0.000 & 0.000 & 0.001 & 0.001 & 0.092 & 0.075 & & 0.373 \\
\hline $\begin{array}{l}\text { Variability of } \\
\text { work } \\
\text { varijabilnost } \\
\text { rada }\end{array}$ & $\{10\}$ & 0.000 & 0.000 & 0.000 & 0.000 & 0.000 & 0.000 & 0.013 & 0.010 & 0.373 & \\
\hline
\end{tabular}

group comprises factors such as job security and variability of work.

Research outcomes proved that FM-company employees were generally satisfied with factors belonging to the the nature of work area. Employees were generally satisfied with physical work demands, given the fact that the work is not physically overly demanding or bound to an assembly line. Each employee was independent in his/her job performance and could set his or her own pace of work. Moreover, many types of work could be done in a comfortable sitting position. As far as the content of work in the field of furniture maufacturing was concerned, the work was not monotonous in any way. The assignments varied and were manifold and interesting, as each product was slightly different or custom-made according to cutomer's needs. Employees were also satisfied with work safety as furniture manufactures pay extra attention to work safety and invariably maintain strict safety regulations.

Finally, FM-company employees were also satisfied with their job security. Their employers often run joint ventures with bigger international enterprises such as IKEA Bratislava s.r.o. and Idea NÁBYTOK Nitra, which usually provide a grounded certainty of long-term working contracts.

\section{CONCLUSION} 4. ZAKLJUČAK

Each enterprise participating in the market economy is well aware of the fact that in order to survive and compete, they have to acquire better results than their competition. That, however, is impossible without productive, loyal and most importantly well-motivated employees. Managers who know what their employees want from work can design a work environment that promotes excellent service by meeting employees' needs and desires. At the same time, informed managers can avoid common pitfalls that reduce employee motivation (Simons and Enz, 1995). Therefore, each company that aims at improvement of work attitudes and work habits of its employees should pay special attention to employee motivation. The need for a better motivation also inspired the present research that fo- 


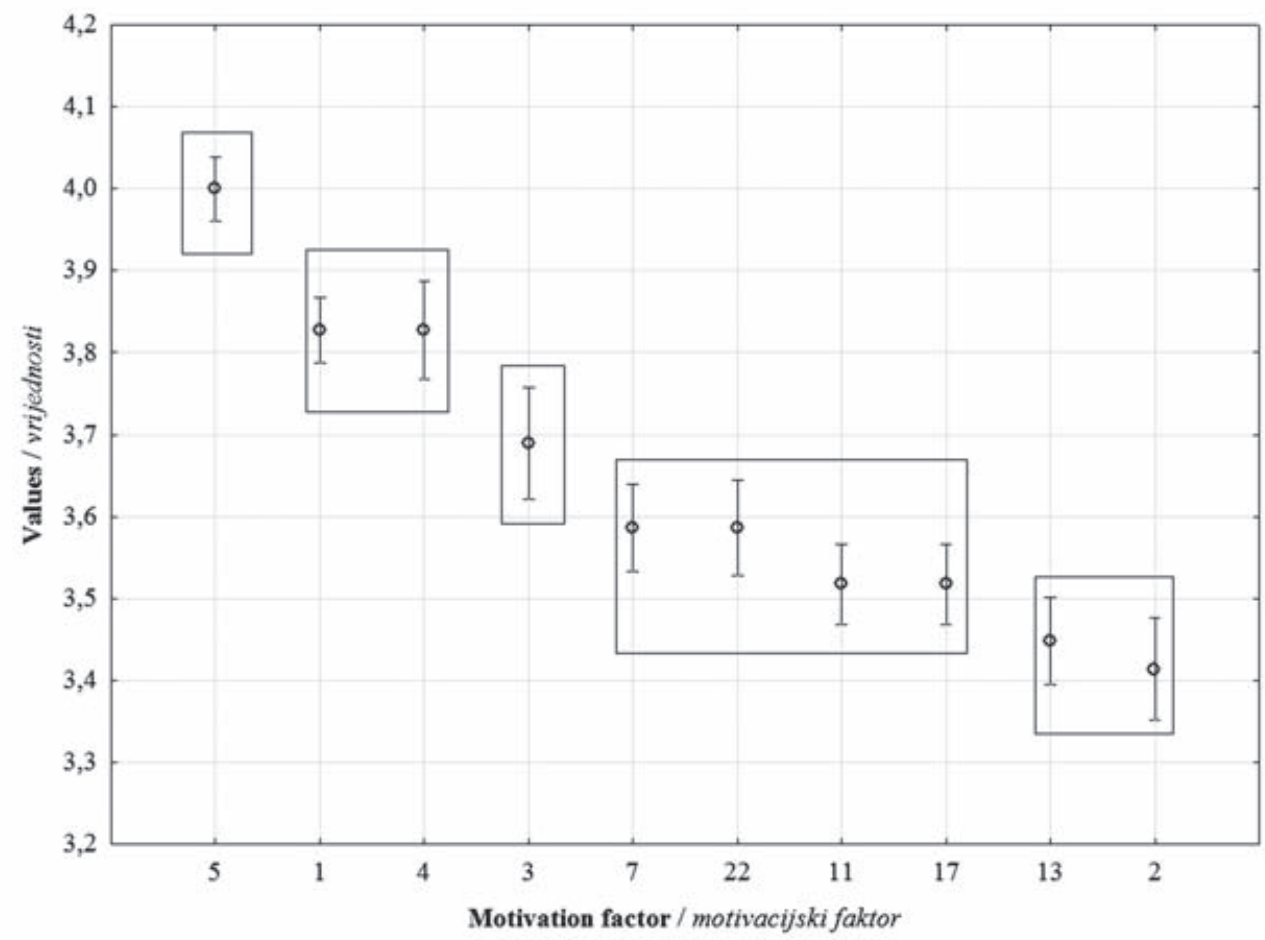

Explanation

Objašnjenje:

5 - Physical work

demands / zahtjevi za

fizičkim radom

1 - "Interestingness" of

work / ,zanimljivosti“

posla

4 - Usefulness of one's

qualification / korisnost

zaposlenikove

kvalifikacije

3 - Work independence

neovisnost u radu

7 - Content of work

sadržaj rada

22 - Working hours

radni sati

11 - Work safety

zaštita na radu

17 - Company's

reputation / ugled tvrtke

13 - Job security

sigurnost radnog mjesta

2 - Variability of work

varijabilnost rada

Figure 6 Representative averages and $95 \%$ confidence intervals of top 10 motivation factors with the highest values according to the criterion: the degree of satifaction

Slika 6. Reprezentativni prosjeci i $95 \%$-tni intervali pouzdanosti deset motivacijskih čimbenika s najvišim vrijednostima prema kriteriju stupanj zadovoljstva

cused on the analysis of those motivation factors that most significantly affect employee job satisfaction in furniture manufacturing companies operating in Slovakia in 2015. In order to gather the most precise data, a questionnaire (focused on the degree of satisfation of various motivation factors, as viewed by employees) has been generated. The degree of motivation was rated on the basis of 36 motivation factors (further organized into 5 sub-cathegories according to their relations to the nature and physical conditions of work, economic conditions of work, logistics and technical conditons of work and interpersonal relationships at workplace). Out of 1,500 respondents, 522 valid questionnaires were collected. Questionnaire responses were bulk-data processed by mathematical and statistical methods, using satistical software program STATISTICA 12, descriptive statistics and inductive statistical methods, including interval estimates and one-way analysis of variance.

Some research revealed that motivation contains factors that motivate and direct one's behaviour (Daft et al., 2000). It has shown that human activities are motivated by one or many known and sometimes unknown complex factors (Možina, 2002). There are individual factors that influence human acitivities, and they are very often part of the human social life (Faletar et al., 2015). According to Závadský et al. (2015), the most commonly used tools of motivation are various incentives, extra holidays, corporate entertaining and rewards. In our research, motivation factors were ordered according to criteria: the degree of satisfaction. Top 10 motivation factors, rated by the employees of Slovak furniture manufacturing companies as the most satisfying, were identified. On the basis of collected data, it can be concluded that 3 most satifying motivations factors for FM-companies in Slovakia in 2015 included physical work demands, "interestingness" of work and usefulness of one's qualification. Supporting our conclusions with the research outcomes, we would like to recommend to the Slovak funiture manufacturing companies to pay special attention to the aforementioned 3 most satisfying motivation factors as these factors significantly affect motivation as well as the overall job performance of employees. Many renowned scholars (Grladinović et al., 2007) agree that motivating the employees is of key importance to increase their efficiency and quality of work. Kampf et al. (2014) point out that the enterprise management should pay dequate attention to motivation programs. Similar positive effects will undoubtedly result not only in enhancement of the overall employee job satisfaction but also in more effective and efficient use of employee work potential, which will eventually lead to more prosperous enterprises. Additional research should be done to gain a continuous view of what motivates people to do their work best. The ability to motivate subordinates is critical to every manager's job. Demographic changes in the workplace, as well as technological advances and globalization, only accentuate the need to continue to determine what motivates people to perform well (Wiley, 1997). A motivated workforce can make powerful contributions to the profits of a firm. 


\section{REFERENCES}

\section{LITERATURA}

1. Aarabi, M. S.; Subramaniam, I. D.; Akeel, A. B. A., 2013: Relationship between Motivational Factors and Job Performance of Employees in Malaysian Service Industry. 9(9): 301-310.

http://dx.doi.org/10.5539/ass.v9n9p301.

2. Ahmad, M. B.; Wasay, E.; Malik, S. U., 2012: Impact of employee motivation on customer satisfaction: Study of airline industry in Pakistan. Interdisciplinary Journal of Conemporary Research in Business, 4(6): 531-539.

3. Alnıaçık, Ü.; Alnıaçık, E.; Akçin, K.; Erat, S., 2012: Relationships Between Career Motivation, Affective Commitment and Job Satisfaction. Procedia-Social and Behavioral Sciences, 58: 355-362.

http://dx.doi.org/10.1016/j.sbspro.2012.09.1011.

4. Anitha, J., 2014: Determinants of employee engagement and the impact on employee performance. International Journalof Productivity and Performance Management, 63(3): 308-323.

http://dx.doi.org/10.1108/IJPPM-01-2013-0008.

5. Antomioni, D., 1999: What motivates middle managers? Industrial Management, 41(6): 27-30.

6. Antošová, M., 2010: Manažment l'udských zdrojov a organizačný rozvoj ako východisko znalostného manažmentu. Acta Montanistica Slovaca, 15(1): 90-95.

7. Bagshawe, A., 2011: How to Improve Motivation. North Yorkshire: Anthony Bagshawe \& Ventus Publishing ApS, p. 63.

8. Bewick, V.; Cheek, L.; Ball, J., 2004: Statistics review 9: One-way analysis of variance.Crit Care, 8(2): 130-136. http://dx.doi.org/10.1186/cc2836.

9. Bowen, B. E.; Radhakrishna, R. B., 1991: Herzberg's motivator hygiene theory and the job satisfaction of agricultural education faculty. Paper presented at the National Agricultural Education Research Meeting, Cincinnati, $\mathrm{OH}$.

10. Čambál, M.; Cagáňová, D., 2010: Corporate Culture Influence on Effective Initialization and Application of Knowledge Management in Enterprises. Famalicao: Academic Publishing International, p. 176-181.

11. Daft, L. R.; Marcic, D., 2000: Understanding Management. London: Thomson learning.

12. Faletar, J.; Jelačić, D.; Sedliačiková, M.; Jazbec, A.; Hajdúchová, I., 2015: Motivating Employees in a Wood Processing Company before and after Restructuring. BioResources, 11(1): 2504-2515.

http://dx.doi.org/10.15376/biores.11.1.2504-2515.

13. Forsyth, P., 2003: Jak motivovat lidi. Brno: Computer Press, p. 117.

14. Greenberg, J.; Baron, A. R., 2003: Behaviour in Organisations. Prentice Hall, 8: 188-215.

15. Grladinović, T.; Oblak, L.; Hitka, M., 2007: Production management information system in wood processing and furniture manufacturing. Drvna industrija, 58: 141-146.

16. Halepota, H. A., 2005: Motivational theories and their application in construction. Cost engineering, 47 (3): 1435.

17. Hellman, C. M., 1997: Job satisfaction and intent to leave. The Journal of Social Psychology, 137: 677-689. http://dx.doi.org/10.1080/00224549709595491.

18. Hitka, M.; Sirotiaková, M., 2011: Impact of economic crisis on change of motivation of Ekoltech s. r. o. Filakovo employees. Drewno wood, 54: 119-126.

19. Hitka, M.; Štípalová, L., 2011: Comparing of Employees Motivation Level in Enterprises of Wood Working Indu- stry with other Manufacturing Enterprises in Slovak Republic. Drvna industria, 62: 185-192. http://dx.doi.org/10.5552/drind.2011.1101.

20. Hitka, M.; Závadská, Z.; Jelačić, D.; Balážová, Ž., 2015: Qualitative indicators of employee satisfaction and their development in a particular period of time. Drvna industrija, 66: 235-239.

http://dx.doi.org/10.5552/drind.2015.1420.

21. Imhof, E., 2003: Comparing occupational and gender differences on motivational structure. Periodica polytechnica, 11 (2): 237-247.

22. Judge, T. A.; Thoresen, C. J.; Bono, J. E.; Patton, G. K., 2001: The job satisfaction - job performance relationship: a qualitative and quantitative review. Psychological Bulletin, 127: 376.

http://dx.doi.org/10.1037/0033-2909.127.3.376.

23. Kachalla, B., 2014: Review of the Role of Motivation on Employee Performance. Mediterranean Journal of Social Sciences. 17: 5, 39-48. http://dx.doi.org/10.5901/mjss.2014.v5n17p39.

24. Kampf, R.; Hitka, M.; Potkány, M., 2014: Interannual differences in employee motivation in manufacturing enterprises in Slovakia. Komunikácie, 4: 98-102.

25. Kampf, R.; Ližbetinová, L., 2015: The Identification and Development of Talents in the Environment of Logistics Companies. Nase more, 62: 139-142.

http://dx.doi.org/10.17818/NM/2015/SI9.

26. Kovach, K. A., 1987: What motivates employees? Workers and supervisors give different answers. Business Horizons, 30 (5), 58-65. https://doi.org/10.1016/0007-6813(87)90082-6.

27. Kucharčíková, A., 2014: The importance of identification and analysis of educational needs for investment in human capital. Komunikacie, 16: 86-92.

28. Marková, V.; Lesníková, P., 2015: Utilization of Corporate Sustainability Concept at Selected Enterprises in Slovakia. Procedia Economics and Finance, 34: 630-637. http://dx.doi.org/10.1016/S2212-5671(15)01678-0.

29. McKenzie-Mohr, D.; Schultz, P. W., 2014: Choosing effective behavior change tools. Social Marketing Quarterly, 20 (1): 35-46. https://doi.org/10.1177/1524500413519257

30. Možina, S., 2002: Management of Human Resources. Fakulteta za Organizacijske Vede, Kranj.

31. Moynihan, D. P.; Pandey, S. K., 2007: Finding workable levers over work motivation: Comparing job satisfaction, job involvement, and organizational commitment. Administration \& Society, 39: 803-832. https://doi.org/10.1177/0095399707305546

32. Muslim, N. A.; Dean, D.; Cohen, D., 2016: Employee Job Search Motivation Factors: An evidence from electricity provider company in Malaysia. Procedia Economics and Finance, 35: 532-540. http://dx.doi.org/10.1016/S2212-5671(16)00066-6.

33. Potkány, M; Giertl, G., 2014: Comparison of selected performance indicators of woodworking industry in the Czech Republic and Slovakia. 7th International Scientific Conference on Position and Role of the Forest Based Sector in the Green Economy: Proceedings of Scientific papers, 7: 131-138.

34. Roos, W.; Van Eeden, R., 2008: The relationship between employee motivation, job satisfaction and corporate culture. SA Journal of Industrial Psychology, 34: 54-63. https://doi.org/10.4102/sajip.v34i1.420

35. Simons, T.; Enz, C. A., 1995: Motivating Hotel Employees: Beyond The Carrot and The Stick. Cornell Hotel and Restaurant Administration Quarterly, 36 (1): 20-27. https://doi.org/10.1016/S0010-8804(99)80053-6 
36. Urbancová, K.; Stachová, K.; Stacho, Z., 2015: Methods of recruitment in the Czech and Slovak organizations. Acta Universitatis Agriculturae et Silviculturae Mendelianae Brunensis, 63: 1051-1060.

http://dx.doi.org/10.11118/actaun201563031051.

37. Vaníčková, R., 2015: Corporate personnel policy and personnel strategy. Klaipeda: Klaipėda University.

38. Vetráková, M.; Potkány, M.; Hitka, M., 2013: Outsoucing of Facility management. Economics and Management, 16: 80-92.

39. Wade, C.; Tavris, C., 2008: Psychology. Upper Saddle River, NJ: Pearson.

40. Závadský, J.; Hitka, M.; Potkány, M., 2015: Changes of employee motivation of slovak enterprises due to global economic crisis. Ekonomie a management, 18: 57-66. http://dx.doi.org/10.15240/tul/001/2015-1-005.

41. Wiley, C., 1997: What motivates employees according to over 40 years of motivation surveys. International Journal of Manpower, 3 (18): 263-280.

http://dx.doi.org/10.1108/01437729710169373.
This paper has been supported by the project VEGA No. 1/0537/16 "Methods and models of strategic management performance and their comparison in enterprises and multinational companies".

\section{Corresponding address:}

Ing. SILVIA LORINCOVÁ, Ph.D.

Technical university in Zvolen Faculty of wood sciences and technology Department of Business Economics T. G. Masaryka 24 96053 Zvolen, SLOVAKIA

e-mail: silvia.lorincova@tuzvo.sk 